\title{
STUDI KOMPETENSI GURU DAN LINIERITAS PENDIDIKAN DALAM PENINGKATAN PRESTASI BELAJAR SISWA DI SD NEGERI 1 GUNUNG TIGA DAN SD NEGERI 1 NGARIP LAMPUNG
}

\author{
Hanif Cahyo Adi Kistoro', Mukminatun Zulviah² Agus Faisal Asyha \\ hanif.kistoro@pai.uad.ac.id \\ Universitas Ahmad Dahlan Yogyakarta ${ }^{1,2}$ \\ Universitas Islam Negeri Raden Intan Lampung ${ }^{3}$
}

\begin{abstract}
A measure of success in education is an excellent and measurable student learning achievement. This study aims to find out how far the relationship between the linear education of teachers and the competence of religious teachers on student achievement in SD Negeri 1 Gunung Tiga and SD Negeri 1 Ngarip Lampung. This research is a qualitative research with a phenomenological approach. The subjects of this study were religious teachers of SD Negeri 1 Gunung Tiga and SD Negeri 1 Ngarip Lampung. Data collection techniques with interviews and data analysis techniques using the Cresswel analysis model. The results of the data analysis showed that based on in-depth interviews with respondents obtained several main themes that support the success of student achievement related to teacher competency. Theme one, religious teachers already have sufficient competence in supporting learning. the competencies seen are pedagogic competence, personality and professional competence. The second theme, success in learning achievement is supported by the linearity of the education of Religious Teachers. The third theme, the existence of educational linearity makes teachers have competence in teaching, especially in learning and professional competencies.
\end{abstract}

Keywords: Competence, Teacher, Learning Achievement

\begin{abstract}
Abstrak
Tolak ukur keberhasilan dalam pendidikan adalah prestasi belajar siswa yang baik dan terukur. Penelitian ini bertujuan untuk mengetahui seberapa jauh hubungan antara linieritas pendidikan guru dan kompetensi guru agama terhadap prestasi belajar siswa di SD Negeri 1 Gunung tiga dan SD Negeri 1 Ngarip Lampung. Penelitian ini merupakan penelitian kualitatif dengan jenis pendekatan fenomenologi. Subyek penelitian ini adalah guru agama SD negeri 1 Gunung tiga dan SD negeri 1 Ngarip lampung. Teknik pengambilan data dengan wawancara dan.teknik analisis data menggunakan model analisis Cresswel. Hasil analisis data menunjukkan bahwa berdasarkan wawancara mendalam kepada responden didapatkan beberapa tema utama yang mendukung keberhasilan prestasi siswa berkaitan dengan kompetensi guru. Tema satu, guru agama sudah mempunyai kompetensi yang cukup dalam menunjang pembelajaran. kompetensi yang dilihat adalah kompetensi pedagogic, kepribadian dan kompetensi professional. Tema kedua, keberhasilan dalam prestasi belajar di dukung dari linieritas pendidikan Guru Agama. Tema ketiga, adanya linieritas pendidikan menjadikan guru mempunyai kompetensi dalam mengajar terutama dalam kompetensi pembelajaran dan professional.

Kata Kunci: Kompetensi, Guru, Prestasi Belajar
\end{abstract}




\section{PENDAHULUAN}

Pendidikan sangatlah penting bagi umat manusia. Tanpa adanya pendidikan manusia tidak dapat mengetahui hakikat kehidupan itu dengan sendirinya. Segala potensi dan bakat yang dimiliki diharap mampu membawa kepada perubahan menuju kearah yang lebih baik. Perubahan ini diharapkan mempunyai pengaruh terhadap tujuan dari pendidikan nasional yang berimplementasi terhadap proses dan hasil dari penyelenggaraan pendidikan itu sendiri (Siswoyo 2008). Salah satu indikator keberhasilan suatu pendidikan dapat dilihat dari prestasi belajar siswa. Menurut Muhibbin Syah dalam buku psikologi pendidikan, "Prestasi belajar adalah tingkat keberhasilan siswa dalam mencapai tujuan yang ditetapkan dalam sebuah program" (Syah 2008). Untuk mencapai prestasi belajar yang optimal, ada 2 faktor yang mempengaruhinya yaitu faktor internal dan faktor eksternal. Faktor internal meliputi faktor jasmaniah, psikologis dan kematangan fisik maupun psikis, sedangkan faktor eksternal meliputi faktor sosial seperti lingkungan keluarga, lingkungan sekolah, lingkungan masyarakat, lingkungan kelompok, faktor budaya, faktor lingkungan fisik seperti fasilitas rumah, fasilitas belajar, iklim, faktor lingkungan spiritual atau keamanan (Ahmadi and Supriyono 2013). Berdasarkan faktor-faktor di atas lingkungan sekolah yang termaksud di dalamnya mencakup kualitas guru merupakan salah satu faktor penting yang menentukan pencapaian hasil belajar dan mempengaruhi tinggi rendahnya prestasi belajar siswa. Karena guru merupakan komponen pengajaran yang memegang peranan penting dan utama dalam proses pembelajaran. Seperti yang sering kita dengar “Guru yang berkualitas menghasilkan pendidikan yang berkualitas"(Sholeh 2006). Bahkan unsur guru dan anak didik ialah yang sangat berperan dalam proses interaksi belajar mengajar, sedangkan unsur lainnya sebagai pendukung (Djamarah 2012). Penelitian sebelumnya yang dilakukan oleh Dudung (2017), menjelaskan bahwa salah satu hal yang penting dalam membentuk kompetensi guru adalah dengan memberdayakan forum guru dalam bidang mata pelajaran. Ditambahkan oleh (Afandi 2016) dalam riset lainnya bahwa dalam proses pembelajaran yang dimulai dari perencanaan, pelaksanaan, evaluasi dan pengembangan kemampuan siswa guru minimal memiliki kompetensi pedagogik, sosial, kepribadian dan professional. 
Selain kompetensi guru, aspek lain yang dianggap mempunyai pengaruh dalam prestasi belajar mata pelajaran adalah kesesuaian latar belakang pendidikan guru dengan mata pelajaran yang diajar. Penelitian yang dilakukan (Oktradisa and Minzani 2018) menunjukkan bahwa linieritas atau kesamaan latar belakang pendidikan dengan mata pelajaran yang diampu mempunyai pengaruh yang besar terhadap keberhasilan prestasi siswa. Perbedaan latar belakang pendidikan akan mempengaruhi kegiatan guru dalam melaksanakan kegiatan interaksi belajar mengajar (Djamarah 2012). Bila profesi keguruan yang sesuai dengan disiplin keilmuan ini ditukar dengan yang bukan ahlinya, maka akan merugikan kegiatan pengajaran. Sebab mereka kurang mampu melaksanakan kegiatan pengajaran dengan baik. Jangankan untuk memberikan ilmu pengetahuan kepada para siswa, mereka sendiri tidak menguasai bahan pelajaran tersebut dengan baik. Jangankan untuk seorang guru yang bukan bidangnya, untuk seorang guru yang sesuai dengan bidangnya pun belum tentu dapat mengajarkannya dengan baik dan benar (Djamarah 2012). Dari uraian di atas dapat dipahami, bahwa latar belakang pendidikan guru atau linieritas pendidikan guru akan mempengaruhi kompetensinya dalam interaksi dan proses belajar mengajar (Djamarah 2012). Terlebih lagi untuk guru pendidikan agama islam yang bukan hanya berperan memberikan ilmu pengetahuan akan tetapi lebih luas dari itu, yaitu membentuk kepribadian dan akhlak siswa. Oleh karena itu proses belajar mengajar akan lebih baik apabila guru tersebut memiliki latar belakang pendidikan yang linier dengan mata pelajaran yang di ampunya atau sesuai dengan disimplin keilmuan dan keahliannya. Apa bila proses belajar mengajar itu berjalan dengan baik maka akan mempengaruhi prestasi belajar peserta didik itu sendiri (Husein 2017).Oleh karena itu, pendidik atau guru sebagai salah satu penentu tercapainya tujuan pendidikan mempunyai pengaruh yang cukup besar terhadap keberhasilan belajar siswa yang kemudian berimplementasi terhadap prestasi belajarnya. Seperti yang disampaikan Dalyono dalam bukunya Psikologi Belajar mengungkapkan bahwa kualitas guru turut mempengaruhi tingkat keberhasilan belajar (Dalyono 2015).

Sebagaimana disebutkan dalam Pasal 7 UU No. 14 tahun 2005 tentang Guru dan Dosen, profesi guru dan profesi dosen merupakan bidang pekerjaan khusus yang di laksanakan berdasarkan beberapa prinsip, salah satu di antaranya adalah guru harus memiliki kualifikasi akademik dan latar belakang pendidikan sesuai dengan bidang 
tugas (Sholeh 2006). Akan tetapi prinsip tersebut tidak boleh berhenti sebatas prinsip, tetapi juga harus diimplementasikan dalam aktivitas sehari-hari. Undang-Undang Republik Indonesia Nomor 14 Tahun 2005 tentang Guru dan Dosen Pasal 24 menyatakan, pemerintah wajib memenuhi kebutuhan guru, baik dalam jumlah, kulifikasi akademik maupun dalam kompetensi secara merata untuk menjamin keberlangsungan satuan pendidikan (Suprihatiningrum 2013). Kondisi sebaran guru yang tidak merata akan melahirkan guru yang harus mengajar bidang studi yang tidak relevan dengan keahliannya (Sholeh 2006). Kurangnya guru yang sesuai disiplin ilmunya, membuat banyak sekolah mensiasati kebutuhan mata pelajaran dengan memberikan tugas kepada guru yang dianggap mampu untuk mengajar mata pelajaran tersebut. Seperti halnya yang terjadi di Sekolah Dasar Negeri 1 Gunung Tiga, sekolah ini memiliki masalah kekurangan guru, terutama guru pendidikan agama islam. Sekolah mempunyai kebijakan mengatasi masalah tersebut dengan merekrut guru yang tidak sesuai pada bidangnya. Lain halnya dengan kondisi di SD Negeri 1 Ngarip yang telah memiliki Guru Pendidikan Agama Islam yang linier dengan bidang studi yang di ampunya. Adanya kondisi yang berbeda antara SD N 1 Gunung Tiga dan SD N 1 ngarip ini mempunyai dampak kepada proses pembelajaran dan hasil belajar siswa.

Penelitian ini bertujuan untuk mengetahui sejauhmana kompetensi guru dan latar belakang pendidikan yang sesuai berkorelasi dengan hasil prestasi belajar siswa. Dalam penelitian ini, peneliti hanya mengfokuskan penelitian kepada aspek kompetensi guru, linieritas pendidikan dan prestasi belajar siswa sesuai dengan pengalaman guru dalam mengajar dan berinteraksi dengan siswa. Menurut Direktorat Profesi Pendidik Tahun 2006 kompetensi adalah kebulatan pengusaan tentang pengetahuan, keterampilan, dan sikap yang ditampilkan melalui unjuk kerja. (Usman 2017)Menurut Kamus Umum Bahasa Indonesia kompetensi berarti kekuasaan untuk menentukan atau memutuskan sesuatu hal. Pengertian dasar kompetensi yakni kemampuan atau kecakapan (Usman 2017). Sesuai dengan ketentuan Undang - undang Repubik Indonesia Nomor 14 tahun 2005 tentang Guru dan Dosen, dijelaskan adanya 4 (empat) kompetensi utama yang harus dimiliki oleh guru. Kompetensi tersebut meliputi kompetensi pedagogik, kompetensi kepribadian, kompetensi social dan kompetensi professional. 
Kemampuan guru dalam mengelola proses pembelajaran disebut dengan kompetensi pedagogik. Mengukur kompetensi pedagogik berdasarkan indikator dari kemampuan memahami wawasan landasan pendidikan, pemahaman terhadap siswa, pengembangan kurikulum, perencanaan pembelajaran, pemanfaatan media dan teknologi pendidikan, mengevaluasi hasil pembelajaran dan melakukan tindak lanjut dalam pengembangan potensi siswa. Dengan kata lain dalam kompetesin pedagogik, guru dituntut mempunyai pemahaman tentang kemampuan dan kondisi siswa. Mampu membuat perencanaan pembelajar dan melaksanakannya. Serta mampu mengevaluasi dan mengembangkan potensi siswa. Kompetensi pedagogik juga akan menunjang dalam kemampuan guru membuat strategi dan metode pembelajaran sesuai dengan kemampuan siswa. Penguasaan terhadap ilmu pengetahuan, teknologi dan seni budaya merupakan wujud dari kompetensi profesional yang harus dimiliki guru. Indikator keberhasilan dari kompetensi ini dapat dilihat dari tingkat penguasaan terhadap keilmuwan yang mendukung mata pelajaran yang diampu, menguasai standar kompetensi dasar dan kompetensi inti dari mata pelajaran yang diampu, mampu mengembangkan materi pelajaran sesuai dengan tingkat pemahaman dan pengetahuan siswa, dan mampu mengembangkan kompentensi secara utuh dan berkelanjutan. Selain itu mempunyai komunikasi yang baik dalam berinteraksi dan memanfaatkan teknologi informasi sebagai media dalam proses pembelajaran.

Kata Linieritas berasal kata Line yang berarti garis, garisan, merk, tali, saluran kawat, lin, jalan, batas, jurusan, perbentengan, deretan, tema. Linier dalam bidang pendidikan adalah kesesuaian antara ijazah atau jurusan yang diambil dengan mata pelajaran yang diampu atau di ajarkan guru di sekolah (riyanto 2016). Secara sederhana linieritas dalam pendidikan mengacu pada 3 hal yaitu linieritas dalam hal penyelenggaraan institusi pendidikan, linieritas bidang ilmu dan linieritas pada bidang kajian. Linieritas institusi berkaitan dengan penyelenggara yang sama meskipun tingkat pendidikan berbeda. Misalnya mahasiswa yang belajar di fakultas ekonomi di jenjang S1 akan sama dengan mahasiswa yang belajar di jenjang S2. Titik poinnya pada penyelenggaranya. Berbeda dengan linieritas bidang ilmu, dalam konsep ini dalam penyelenggaran pendidikan akan mempunyai konsentrasi yang berbeda. Misalnya dalam jurusan pendidikan, ada pendidikan umum dan pendidikan agama. Masing- 
masing mempunyai bidang kajian sesuai bidang ilmunya. Linieritas dalam bidang kajian akan menekankan pada kajian yang di minati meskipun berbeda institusi dan bidang ilmunya. Guru yang linear pada umumnya lebih kompeten sehingga guru yang lebih berkompeten ini nyatanya lebih professional dalam pengerjaan tugasnya menjadi seorang guru. Hal ini dapat menghasilkan sesuatu yang baik bagi siswa dari profesionalnya seorang guru. Lineritas pendidikan guru lebih signifikan berkorelasi dibandingkan dengan pengalaman mengajar. Dan kecenderungan linearitas pendidikan formal guru dan pengalaman mengajar semakin baik tentunya akan memberikan pengaruh yang jauh lebih baik terhadap penguasaan pedagogik (Wijaya and Supriyanto 2018).

Berdasarkan pengertian diatas definsi operasional linieritas dalam penelitian ini adalah kesesuaian antara ilmu pendidikan yang di pelajari secara formal dengan tugas yang diampu khususnya dalam mengajar. Adanya keseuaian ini diharapakan akan mempermudah dalam melaksanakan proses pembelajaran dan diharapakan dapat meningkatn kompetensi profesional guru. Hal ini diperkuat dari penelitian sebelumnya, yang menjelaskan bahwa pendidikan yang sesuai dan ditempuh guru dalam pendidikan formal secara teori akan membentuk kompetensi guru lebih professional (Komalasari 2015). Prestasi belajar dibidang pendidikan adalah hasil dari pengukuran terhadap siswa yang meliputi faktor kognitif, efektif, dan psikomotorik setelah mengikuti proses pembelajaran yang diukur dengan menggunakan instrument tes atau instrument yang relevan. Jadi prestasi belajar adalah hasil pengukuran dari penilaian usaha belajar yang dinyatakan dalam bentuk symbol, huruf maupun kalimat yang mencerikatan hasil yang sudah dicapai oleh setiap anak pada periode tertentu (Hamdani 2011).

Prestasi belajar merupakan kemampuan yang dimiliki siswa setelah ia menerima pengalaman belajarnya. Prestasi belajar tidak hanya dilihat dari hasil akhirnya tetapi juga dari proses pembelajaran. Ini berarti bahwa prestasi belajar siswa juga dapat bergantung pada proses belajar siswa dan proses mengajar guru. Oleh sebab itu, dalam proses pembelajaran juga perlu dilakukan penilaian (Sujana 2005). Salah satu upaya untuk menjadikan seseorang berpreastasi adalah dengan melakukan suatu kegiatan yang berkelanjutan. Artinya, ketika seseorang sadar akan potensi diri yang dimilikinya maka ia akan selalu berusaha untuk mengembangkan kemampuannya hingga menjadi 
kemampuan utama. Prestasi merupakan hasil usaha dari pengembangan bakat diri seseorang secara terus-menerus. Hasil belajar tersebut adalah prestasi belajar siswa yang dapat diukur dari data nilai siswa setelah melakukan evaluasi pembelajaran berupa soal yang diberikan oleh guru (Siagian 2012). Definsi prestasi belajar dalam penelitian ini adalah hasil akhir setelah siswa mengalami proses belajar, dimana tingkah laku berubah dalam bentuk perbuatan yang dapat diamati dan dapat diukur. Dengan kata lain prestasi belajar siswa merupakan proses pembelajaran yang sudah dilakukan dalam bentuk nilai akhir.

\section{METOE PENELITIAN}

Penelitian ini menggunakan pendekatan fenomenologi sesuai jenis riset kualitatif. Pendekatan fenomenologi merupakan pendekatan dalam penelitian yang akan menggali pengalaman yang dialami dari subyek secara mendalam (Moutakas 1994).

Subjek yang digunakan adalah guru agama di SD N 1 Gunung Tiga dan SD N 1 Ngarip yang berjumlah 6 orang, terdiri dari 4 guru agama dan 2 kepala sekolah. Penentuan partisipan dalam penelitian ini menggunakan teknik purposive, dimana informan dipilih sesuai dengan ketentuan yaitu guru agama islam dan kepala sekolah. Penelitian ini dilaksanakan mulai bulan mei sampai juni 2019. Diawali tahapan observasi awal sebagai salah satu teknik pengambilan data untuk mengetahui sistem pembelajaran yang dilakukan. Teknik berikutnya dalam pengambilan data dilanjutkan dengan wawancara mendalam terhadap responden/partisipan untuk mendapatkan informasi lebih banyak berkaitan dengan pengalaman menjadi guru agama dan strategi pembelajaran yang digunakan. Teknik analisis data menggunakan model analisis Cresswel yang melalui prosedur tahapan pengambilan data, reduksi data dan interpretasi data. Sesuai jenis pendekatan fenomenologi yang dilakukan maka dalam analisis data tahap pengambilan data sudah sesuai prosedur dan didapatkan hasil berjumlah 6 transkrip wawacara dengan teknik verbatim.

\section{HASIL PENELITIAN DAN PEMBAHASAN}

Berdasarkan hasil kesimpulan dari 6 transkrip data wawancara dari responden. Di temukan 3 tema besar yang menunjukkan adanya pengaruh kompetensi dan linieritas pendidikan guru terhadap prestasi siswa. Tema satu, guru agama sudah mempunyai 
kompetensi yang cukup dalam menunjang pembelajaran. kompetensi yang dilihat adalah kompetensi pedagogik, kepribadian dan kompetensi professional. Hal ini di perkuat dari hasil wawancara dengan kepala sekolah SD Negeri 1 Gunung Tiga (Siti Nasbah: Senin, 17 Juni 2019) : “Guru Pendidikan agama Islam di sekolah ini merupakan guru lulusan PGSD, karena sekolah ini masih kekurangan guru untuk mengampu mata pelajaran Pendidikan Agama Islam. Secara keilmuan guru mempunyai kompetensi yang cukup. Untuk kekurangan kemampuan materi agama, guru di berikan pelatihan materi pendidikan agama. Hasilnya guru dapat mengajar dengan baik dan murid juga mendapatkan hasil yang baik pula”. Makna kompetensi di sini adalah untuk kompetensi pedagogik, sosial, dan professional guru sudah sesuai karena merupakan lulusan dari jurusan pendidikan. Sementara dalam materi agama, guru diberikan pelatihan khusus dan guru mampu memberikan contoh pengamalan materi agama. Sehingga secara umum guru juga mempunyai kompetensi kepribadian yang baik. Begitu pula yang ada di SD Negeri 1 Ngarip. Guru sudah mempunyai kompetensi yang baik. Tema kedua, keberhasilan dalam prestasi belajar di dukung dari linieritas pendidikan Guru Agama. Seperti yang disampaikan oleh dengan guru agama di SD Negeri Ngarip (Ilham Dani, S.Ag: selasa, 18 Juni 2019), linieritas dari background pendidikan guru sudah sesuai yaitu dari lulusan pendidikan guru agama: "Sebagai guru yang mengampu mata pelajaran Pendidikan Agama Islam saya mempunyai latar belakang Pendidikan Agama Islam" dengan latar belakang pendidikan yang sama, dapat memudahkan saya dalam melaksanakan pembelajaran”. Selain hasil dari wawancara, dari hasil prestasi juga menunjukkan bahwa nilai- rata-rata siswa sebesar 81\%. Tema ketiga, adanya linieritas pendidikan menjadikan guru mempunyai kompetensi dalam mengajar terutama dalam kompetensi pedagogik dan profesional. Strategi pengajaran dari guru yang mempunyai kompetensi pedagogik dan professional cenderung dinamis dengan metode yang disesuaikan dengan kemampuan siswa.

Kesimpulan terakhir adalah adanya kompetensi guru dan kesesuaian latar pendidikan guru agama mempunyai pengrauah dalam proses pembelajaran dan prestasi belajar siswa di SD Negeri 1 Gunung Tiga dan SD Negeri 1 Ngarip. Hasil akhri dari prestasi siswa yang di ampu guru yang linier latar belakang pendidikannya dan tidak linier pendidikannya hanya berbeda sedikit nilainya. Hal ini dikarenakan pihak sekolah 
memberikan tambahan materi guru yang bukan lulusan pendidikan agama islam dalam bentuk pelatihan. Hal ini yang menarik dari hasil penelitian, bahwa sekolah mempunyai kebijakan dan keinginan kuat untuk mendapatkan hasil maksimal dalam pendidikan agama dengan memberikan fasilitas guru yang bukan dari lulusan pendidikan agama islam dengan penambahan materi kompetensi. Selain itu, guru agama dapat memberikan contoh atau tauladan yang baik dalam perilaku dan perkataannya.

\section{SIMPULAN DAN SARAN}

Berdasarkan hasil analisis dan pembahasan dapat disimpulkan bahwa kompetensi guru dan linieritas pendidikan mempunyai peran lebih dalam prestasi siswa di SD Negeri 1 Gunung tiga dan SD Negeri 1 Ngarip. Pendidikan guru Agama Islam di SD Negeri 1 Gunung Tiga tidak linier dengan mata pelajaran yang diampunya, karena guru tersebut merupakan lulusan Sarjana Pendidikan Guru Sekolah Dasar (PGSD). Meskipun tidak linier, tetapi guru agama dapat memebrikan pembelajaran yang baik karena diberikan bekal tambahan materi agama dalam bentuk pelatihan. Prestasi belajar siswa di SD Negeri 1 Gunung Tiga yang diampu oleh guru yang tidak linier mempunyai nilai selisih sedikit dengan SD Negeri 1 Ngarip yang diampu oleh guru yang linier. Secara umum persoalan kekurangan sumber daya manusia guru untuk mata pelajaran pendidikan agama islam meskipun menjadi persoalan mendesak tetapi dapat di siasati oleh pihak sekolah dengan memberikan tambahan materi pendidikan agama bagi guur yang mengampu dalam bentuk pelatihan dan lainnya. Adapun saran yang dapat diberikan adalah adanya pengaruh dari linieritas pendididikan dan kompetensi guru terhadap prestasi belajar siswa diharapkan pihak sekolah khususnya kepala sekolah untuk mengambil keputusan dalam hal rekruitmen guru bidang studi dan penempatannya sesuai dengan bidang kompetensi yang dimilikinya. Berdasarkan keterbatasan yang dipaparkan oleh peneliti pada bab sebelumnya maka diharapkan bagi peneliti selanjutnya yang akan meneliti dengan tema pengaruh linieritas pendidikan dan kompetensi guru terhadap prestasi belajar siswa dapat melakukan penelitian mengenai faktor-faktor lain yang mempengaruhi prestasi belajar siswa. Semoga hasil penelitian ini dapat menjadi rujukan bagi penelitian selanjutnya. 


\section{DAFTAR PUSTAKA}

Afandi, Muhammad. 2016. "Kompetensi Guru Sebagai Kunci Keberhasilan Dalam Pembelajaran Saintifik." Seminar Nasional Pendidikan Purwokerto : Universitas muhammadiyah Purwokerto.

Ahmadi, Abu, and Widodo Supriyono. 2013. Psikologi Belajar. Jakarta: PT Rineka Cipta.

Dalyono. 2015. Psikologi Pendidikan. Jakarta: PT. Rineka Cipta.

Djamarah, Syaiful Bahri. 2012. Prestasi Belajar Dan Kompetensi Guru. Surabaya: Usaha Nasional.

Hamdani. 2011. Strategi Belajar Mengajar. Bandung: CV. Pustaka Setia.

Husein, Latif. 2017. Profesi Keguruan Menjadi Guru Profesional. Yogyakarta: PT. Pustaka Baru Press.

Komalasari, Febyana Putri. 2015. "Profesionalisme Guru Ditinjau Dari Pendidikan Dan Latihan Serta Pengalaman Mengajar Di Smp Negeri Se- Kecamatan Delanggu Tahun 2014." Prosiding Semiar Nasional Pendidikan Ekonomi \& Bisnis Fakultas Keguruan Dan Ilmu Pendidikan: Universitas Sebelas Maret Surakarta.

Moutakas, Clarck E. 1994. Phenomenological Research Methods. New Delhi: Sage Publication India.

Oktradisa, Ahwy, and Aufi Minzani. 2018. "Studi Evaluasi Kinerja Guru Kelas Mi Bersertifikasi Ijazah Non- Pgmi Terhadap Kompetensi Pedagogik Dan Profesional Di Kabupaten Magelang." Pendas: Jurnal Ilmiah Pendidikan Dasar III (01).

riyanto. 2016. "Implementasi Undang-Undang Nomor 14 Tahun 2005 Pasal 7 Poin c Tentang Guru Dan Dosen Di Madrasah Aliyah Se Kabupaten Kampar.” Thesis.

Sholeh, Asronun Niam. 2006. Membangun Profesionalitas Guru. Jakarta: Eslas Jakarta.

Siagian, Roida Eva Flora. 2012. "Pengaruh Minat Dan Kebiasaan Belajar Siswa Terhadap Prestasi Belajar Matematika.” Jurnal Formatif II (2).

Siswoyo, Dwi. 2008. Ilmu Pendidikan. Yogyakarta: UNY Press.

Sujana, Nana. 2005. Penilaian Hasil Prose Belajar Mengajar. Bandung: PT Remaja Rosdakarya.

Suprihatiningrum, Jamil. 2013. Guru Profesional. Yogyakarta: Ar-Ruzz Media. 
Syah, M. Muhibbin. 2008. Psikologi Pendidikan. Bandung: PT. Remaja Rosdakarya.

Usman, Moh Uzer. 2017. Menjadi Guru Profesional. Bandung: PT Remaja Rosdakarya.

Wijaya, Ferri Zal, and Didik Supriyanto. 2018. "Pengaruh Linieritas Pendidikan Formal Guru Terhadap Kompetensi Pedagogik Di Madrasah Ibtidaiyah Salafiyah Syafi'iyah 1 Sooko Mojokerto.” Proceedings Internasional Seminar III III (2). 